\title{
Seasonal patterns of basal and GnRH-induced LH, FSH and testosterone secretion in Eld's deer stags (Cervus eldi thamin)
}

\author{
S. L. Monfort ${ }^{1,2}$, J. L. Brown ${ }^{1,2}$, T. C. Wood ${ }^{1,2}$, C. Wemmer ${ }^{1}$, \\ A. Vargas ${ }^{1}$, L. R. Williamson ${ }^{1}$ and D. E. Wildt ${ }^{1,2}$ \\ ${ }^{1}$ National Zoological Park, Departments of Animal Health and Conservation, Smithsonian Institution, \\ Front Royal, VA 22630, USA; and '2Department of Biology, Environmental Biology and Public \\ Policy, George Mason University, Fairfax, VA 22039, USA
}

\begin{abstract}
Plasma LH, FSH and testosterone were measured in blood samples collected via remote catheterization from six adult Eld's deer stags every $10 \mathrm{~min}$ for $8 \mathrm{~h}$ before and $2 \mathrm{~h}$ after $\mathrm{GnRH}$ ( $1 \mu \mathrm{g} \mathrm{kg}^{-1}$, i.v.) administration. Blood samples were collected within 2 weeks of the summer solstice (21 June), autumn equinox (22 September), winter solstice (21 December) and spring equinox (20 March). Marked seasonal variations in basal LH, FSH and testosterone concentrations were observed. From autumn, well-defined LH pulses were temporally associated with small, but detectable pulses in testosterone. During the winter transition into the breeding season, episodic $\mathrm{LH}$ pulses were also temporally associated with corresponding testosterone surges that lasted 2-3 h. High amplitude, low frequency testosterone surges were also observed during the spring, but often in the absence of detectable LH pulses. Basal LH and testosterone concentrations decreased during the summer and, although $\mathrm{LH}$ pulses were detected, associated testosterone pulses were absent. Only $37 \%$ of $\mathrm{LH}$ pulses occurred coincidentally with FSH pulses, and FSH pulses were generally less prominent. The increases in LH and FSH above basal concentrations after GnRH treatment were significant $(P<0.05)$ for all seasons. Increases in testosterone after $\mathrm{GnRH}$ treatment were greatest during the winter and spring, but testosterone also increased to a lesser extent during the autumn $(P<0.05)$. In contrast, testosterone concentrations were not different before and after GnRH treatment during summer. The net $\mathrm{LH}$ increase after GnRH treatment was similar $(P>0.05)$ for all seasons, whereas the proportional increase in $\mathrm{LH}$ was greatest $(P<0.05)$ during the summer and autumn when basal concentrations were lowest. Although the net FSH increase after $\mathrm{GnRH}$ treatment ranged only from 20 to $40 \mathrm{ng} \mathrm{ml}^{-1}$ during all seasons, the proportional rise in FSH after GnRH treatment tended to be highest during the summer and autumn when basal concentrations were lowest. Basal testosterone secretion and the net increase in testosterone after $\mathrm{GnRH}$ treatments were greatest during the spring rut $(P<0.05)$. Thus, in Eld's deer, it appears that pituitary gonadotrophs seasonally adjust their basal secretory 'set point', but the capacity to respond above basal concentrations is constrained to a maximum net increase in both $\mathrm{LH}$ and $\mathrm{FSH}$, regardless of season. Because both basal $\mathrm{LH}$ and the net releasable pool of $\mathrm{LH}$ remain relatively constant, increased testosterone secretion after $\mathrm{GnRH}$ treatment probably represents increased testicular sensitivity to $\mathrm{LH}$.
\end{abstract}

\section{Introduction}

The Burmese brow-antlered deer, or Eld's deer (Cervus eldi thamin), is sparsely distributed from eastern India to Indochina and southern China $\left(3^{\circ}-25^{\circ} \mathrm{N}\right.$ latitude). Eld's deer represent a striking example of a subtropical species that does not exhibit a latitudinal shift in the timing or duration of annual reproductive rhythms, expressing pronounced seasonality in its native habitat as well as at northern, temperate latitudes $\left(38^{\circ} \mathrm{N}\right)$ (Monfort et al., 1993). Unlike most temperate cervid

Received 21 August 1992. species, the circannual hypothalamic-pituitary-gonadal cycle of the Eld's deer stag begins with pituitary activation during autumn and winter, and peak testis size, testosterone secretion, rutting behaviour and maximal sperm production occurring during winter and spring, as daylengths increase (Monfort et al., 1990; 1993).

The seasonal cycle of antler growth, body weight, neck and chest girth in Eld's deer (Monfort et al., 1993) is qualitatively similar to that of red deer (Cervus elaphus, Suttie et al., 1984), chital (Axis axis, Loudon and Curlewis, 1988) and fallow deer (Dama dama, Asher et al., 1989). However, for the Eld's deer, these rhythms are shifted 6 months out-of-phase relative to 
most temperate cervids. Despite the seasonal phase difference, the interactive dynamics of the pituitary-gonadal axis in Eld's deer (Monfort et al., 1993) is remarkably similar to red deer stags (Lincoln and Kay, 1979) and fallow deer bucks (Asher et al,, 1989). Antler growth begins before LH and FSH increase and continues while LH and FSH concentrations are high and testosterone and prolactin are low (Monfort et al., 1993). As in other deer studied, antler mineralization, velvet stripping and rut occur when testosterone is high, whereas casting occurs after testosterone has declined (Suttie et al., 1984). Peak FSH secretion in Eld's deer occurs 3 months later than the LH peak, closely paralleling the cycle of testosterone secretion and sperm production (Monfort et al., 1993). Overall, these data are similar to observations in white-tailed deer (Odocoileus virginianus, Mirarchi et al., 1978; Bubenik et al., 1982), roe deer (Capreolus capreolus, Sempère and Lacroix, 1982) and red deer (Suttie et al., 1984) and can be interpreted to suggest that LH plays a critical role in initiating testicular steroidogenic activity. In contrast, FSH and testosterone appear to be important for supporting later spermatogenesis, during the peak of the circannual testicular cycle.

The short-term secretory dynamics of $\mathrm{LH}$ and testosterone secretion have been well-characterized only in red deer (Lincoln and Kay, 1979; Suttie et al., 1984; Fennessy et al., 1988) and fallow deer (Asher et al., 1989; Asher and Peterson, 1991), whereas hour-to-hour basal FSH secretion patterns have not been described for any cervid. Pituitary or gonadal responsiveness to an exogenous $\mathrm{GnRH}$ challenge has been studied in white-tailed deer (Plotka et al., 1984; Bubenik et al., 1987), red deer (Lincoln and Kay, 1979; Suttie et al., 1984; Fennessy et al., 1988) and rusa deer (Cervus rusa timorensis, van Mourik et al., 1986), and only one report (white-tailed deer, Bubenik et al., 1987) has described seasonal pituitary FSH responsiveness to an exogenous $\mathrm{GnRH}$ challenge. Thus, the existing database describing seasonal changes in the secretory dynamics of the reproductive axis of male deer has been almost exclusively derived from studies of three temperate species. There is no information describing the hourto-hour secretory changes in gonadotrophins and testosterone in any tropical cervid species.

The Eld's deer represents a unique opportunity to study the interrelationships between the hypothalamic-pituitary-gonadal axis in a subtropical, endangered species that expresses a reproductive rhythm 6 months out-of-phase with temperate cervid species. The present study used a remote catheterization technique that permitted repeated collection of blood samples from unanaesthetized, unrestrained stags. Our objectives were to (i) investigate the temporal secretory dynamics of basal $\mathrm{LH}, \mathrm{FSH}$ and testosterone, (ii) compare GnRH-induced pituitary and gonadal responsiveness during the summer, autumn, winter and spring and (iii) relate our findings to the existing database for temperate cervid species.

\section{Materials and Methods}

\section{Animals and treatments}

Six adult Eld's deer stags (2-8 years of age; $70-120 \mathrm{~kg}$ body weight) maintained at the Smithsonian Institution's Conservation and Research Center, Front Royal, VA $\left(38^{\circ} \mathrm{N}\right)$ were used in the study. Males were housed individually in indoor stalls (3.4 $\mathrm{m} \times 4.6 \mathrm{~m}$ with skylights) connected to outdoor enclosures $(3.6 \mathrm{~m} \times 36.6 \mathrm{~m})$ and exposed to natural fluctuations in photoperiod. Individuals were maintained within visual proximity to other males and within auditory and olfactory proximity to conspecific adult males and females.

\section{Collection of blood samples}

Blood samples were collected every $10 \mathrm{~min}$ for $8 \mathrm{~h}$ before and $2 \mathrm{~h}$ after GnRH (Cystorelin: Abbott Laboratories, Chicago, IL; $1 \mu \mathrm{g} \mathrm{kg}^{-1}$, i.v.) administered within 2 weeks of the summer solstice (21 June), autumn equinox (22 September), winter solstice (21 December) and spring equinox (20 March). On the afternoon before the day of collection of serial blood samples, each stag was sedated using xylazine (Rompun: Mobay Corp., Shawnee, $\mathrm{KA}$; $0.3-0.5 \mathrm{mg} \mathrm{kg}^{-1}$, i.m.), and dual i.v. jugular catheters (16 gauge $\times 22.9 \mathrm{~cm}$, Centrasil: Baxter Healthcare Corp., Deerfield, IL) were inserted, sutured into place and connected to a $76 \mathrm{~cm}$ extension tube (Abbott Hospitals, Inc., Chicago IL, USA). The extension line was coiled, covered with bandage, and catheters then were flushed with heparinized saline $\left(10 \mathrm{ml}, 30 \mathrm{iu} \mathrm{ml}{ }^{-1}\right)$ to prevent intracannula clotting. Males were placed in a $1.8 \mathrm{~m} \times 0.9 \mathrm{~m}$ stall where blood was to be collected via remote catheterization the next day beginning at 08:00 h. On the day of blood collection $(07: 30 \mathrm{~h})$, two animal handlers entered the collection stall, accessed the short extension line $(76 \mathrm{~cm}$ line) from underneath the bandage, and connected another salinefilled extension line $(150 \mathrm{~cm})$ to permit remote removal of blood from outside the stall. Individual blood samples were collected while stags were fully conscious (at least $18 \mathrm{~h}$ after full recovery from anaesthesia). During the sampling interval (about 08:0020:00 h), stags were able to stand, recline and turn around comfortably; alfalfa hay and water were provided ad libitum during this time. To obtain each blood sample, a syringe attached to a three-way stopcock was used to aspirate saline through the line until undiluted blood was collected. Blood samples (about $3 \mathrm{ml}$ ) were transferred into heparinized tubes, placed on ice, centrifuged $(1500 \mathrm{~g}, 20 \mathrm{~min})$ within $2 \mathrm{~h}$, and plasma was stored at $-70^{\circ} \mathrm{C}$ until analysed. The extension line was then flushed with either $25 \mathrm{ml}$ heparinized $\left(5 \mathrm{iu} \mathrm{ml}^{-1}\right)$ or nonheparinized saline on alternate blood draws to prevent clot formation.

\section{Luteinizing hormone assay}

Serum LH was analysed using a heterologous, ${ }^{125} \mathrm{I}$ doubleantibody radioimmunoassay which used a rabbit anti-ovine $\mathrm{LH}$ antiserum (PKC-231A, J. L. Brown) as the first antibody, purified ovine LH (LER-1056-C2, L. E. Reichert, Jr, Albany Medical College, Albany, NY) as the tracer and ovine LH (NIH-LH-SI8, National Pituitary Program, Baltimore, MD) as the standard (Brown et al., 1991). Serial dilutions of pooled Eld's deer plasma yielded displacement curves parallel to that obtained for the $\mathrm{LH}$ standard. The mean recovery of ovine LH (range 0.03-4.00 ng per tube) added to Eld's deer plasma, after subtraction of endogenous hormone, was $99.3 \pm 3.8 \%(y=1.03 x+0.005$, $r^{2}=0.98, P<0.001$ ). Assay sensitivity, calculated as $90 \%$ of maximum binding, was $0.03 \mathrm{ng}$ per tube. The interassay coefficients of variation for two separate internal controls were $10.0 \%$ and $9.9 \%$; intra-assay variation was $<10 \%$. 


\section{Follicle-stimulating hormone assay}

Serum FSH was measured using a heterologous, ${ }^{125}$ I doubleantibody radioimmunoassay with a rabbit anti-ovine FSH antiserum (JADLER 178, J. A. Dias, Wadsworth Research Institute, Albany, NY), purified ovine FSH (LER-1976-A2, L. E. Reichert, Jr) tracer and ovine FSH (NIH-FSH-88, National Pituitary Program) standards (Brown et al., 1987). Serial dilutions of pooled Eld's deer plasma yielded displacement curves parallel to that obtained with the standard preparation. The mean recovery of ovine FSH (range $0.78-100 \mathrm{ng}$ per tube), after subtraction of endogenous hormone, was $102.3 \pm 4.4 \%(y=1.06 x+0.34$, $r^{2}=0.99, P<0.001$ ). Assay sensitivity was $0.5 \mathrm{ng}$ per tube. The interassay coefficients of variation for two separate internal controls was $11.5 \%$ and $14.4 \%$, respectively; intra-assay variation was $<10 \%$.

\section{Testosterone assay}

Serum testosterone was analysed in unextracted plasma using a ${ }^{125}$ I radioimmunoassay kit (ICN, Costa Mesa, CA). Serial dilutions of plasma yielded displacement curves parallel to that obtained with the standard preparation. The mean recovery of testosterone (range $0.1-10 \mathrm{ng} \mathrm{ml}^{-1}$ ) added to pooled Eld's deer plasma was $99.4 \pm 3.1 \% \quad\left(y=1.01 x-0.002, r^{2}=0.99\right.$, $P<0.001$ ). Assay sensitivity was $0.1 \mathrm{ng} \mathrm{m}^{-1}$. The interassay coefficient of variation was $12.9 \%$, and intra-assay variation was $<10 \%$.

\section{Statistical analyses}

Hormone concentrations are represented as means \pm SEM. All statistical comparisons were performed using Statview $512+$ (BrainPower, Inc., Calabasas, CA) on a Macintosh computer. Among-season comparisons of pulse detection data, as well as among-and within-season comparisons of hormone concentrations before and after GnRH treatment were determined by repeated measures analysis of variance. Multiple pairwise contrasts were performed using Fisher's protected least significant difference test. The net increase in hormone concentrations was defined as the mean hormone concentration after GnRH treatment ( $n=12$ samples) minus the mean basal hormone concentration ( $n=3$ samples before $\mathrm{GnRH}$ administration). Because of within-animal fluctuations in hormone secretion patterns, the baseline before GnRH treatment was calculated as the mean of the three samples collected immediately before $\mathrm{GnRH}$ administration. The proportional increase in hormone concentration was defined as the mean hormone concentration after $\mathrm{GnRH}$ minus the mean basal hormone concentration, divided by the mean basal hormone concentration, expressed as a percentage. Correlation coefficients were calculated to determine the correspondence between $\mathrm{LH}$ and FSH profiles.

Cluster Analysis (Veldhuis and Johnson, 1986; version 5.0), a statistically-based pulse detection algorithm, was used to analyse pulsatile LH, FSH and testosterone secretion before $\mathrm{GnRH}$ administration. A $2 \times 1$ ( 2 nadir points $\times 1$ peak point) cluster size was used for $\mathrm{LH}$ (constant coefficient of variation $=10 \%$ ) and a $2 \times 2$ cluster configuration was chosen for FSH and testosterone (constant coefficients of variation, $\mathrm{FSH}=12 \%$; testosterone $=10 \%$ ). Pooled $t$ statistics of 2.0 were chosen for pulse detection analyses for all hormones. The specific cluster configuration and $t$ statistic were selected to limit the false pulse detection rate to about $5 \%$. This program estimated all possible increases in the data series when successive nadir clusters (two data points) were compared against immediately successive potential pulse regions (one or two data points). All significant decreases within the data series were also analysed with reference to this particular cluster configuration. The mean pulse height as a percentage increase represents the percentage increase of the mean pulse amplitude above the preceding nadir value. The largest pulse height above basal represented the incremental increase of the largest value expressed as the algebraic difference between the largest value and the preceding nadir.

\section{Results}

All Eld's deer stags in the present study exhibited marked $(P<0.05)$ seasonal variations in basal concentrations of $\mathrm{LH}$, FSH and testosterone. Basal secretory patterns and responsiveness to GnRH from two representative individuals (Fig. 1a, b) were typical of seasonal profiles observed in all stags. During the winter transition into the breeding season, distinct testosterone surges (mean increase above basal $1.8 \pm 0.3 \mathrm{ng} \mathrm{ml}^{-1}$; mean duration $149.2 \pm 6.8 \mathrm{~min}$; mean duration range $130-175 \mathrm{~min}$ ) were always preceded by $30-40 \mathrm{~min}$ by $\mathrm{LH}$ pulses. During the spring rut, high amplitude (mean increase above basal $3.3 \pm 1.0 \mathrm{ng} \mathrm{ml}^{-1}$ ) testosterone surges (mean duration $120.0 \pm$ $18.0 \mathrm{~min}$; mean duration range $72-168 \mathrm{~min}$ ) were also observed, but only $56 \%$ (9 of 16 ) of these surges were preceded by LH pulses. Mean basal LH secretion decreased $(P<0.05)$ from $3.3 \pm$ $0.4 \mathrm{ng} \mathrm{ml}^{-1}$ during the spring rut to $1.9 \pm 0.1 \mathrm{ng} \mathrm{ml}^{-1}$ during the summer, after the breeding season. Spontaneous testosterone pulses or surges were absent during the summer, but small testosterone pulses were observed coincident with LH pulses (see insets, Fig. 1) during the autumn. For all seasons, only $37 \%$ of LH pulses were secreted coincidentally with $\mathrm{FSH}$ pulses, and the latter were generally less prominent than were $\mathrm{LH}$ pulses. Overall mean correlations between $\mathrm{FSH}$ and $\mathrm{LH}$ secretion during 24 , 8 -h basal sampling intervals was $r=0.38 \pm 0.05$. Correspondence between FSH and LH was greater $(P<0.05)$ in the autumn than in the summer (seasonal $r$ values: autumn, $0.56 \pm 0.09$; winter, $0.35 \pm 0.08$; spring, $0.41 \pm 0.09$; summer, $0.20 \pm 0.07$ ).

Quantitative pulse detection analyses were performed for LH, FSH and testosterone for each 8-h data series before $\mathrm{GnRH}$ treatment (Table 1). LH pulse frequency was greater during the summer $(P<0.05)$ than in all other seasons, whereas no seasonal differences $(P>0.05)$ were detected in the mean pulse heights expressed as a percentage increase over basal concentrations, or in the largest observed pulse height above basal concentrations. FSH pulse frequencies during the summer and autumn were greater $(P<0.05)$ than during the winter, but not the spring $(P<0.05)$; pulse frequencies during winter and spring were similar $(P>0.05)$. No seasonal differences were found in the mean FSH pulse heights expressed as a percentage increase over basal concentrations, or in the largest observed pulse height above basal concentrations $(P>0.05)$. For testosterone, pulse frequency observed during the winter and spring was greater than that in summer. Although pulse height above 
(a)
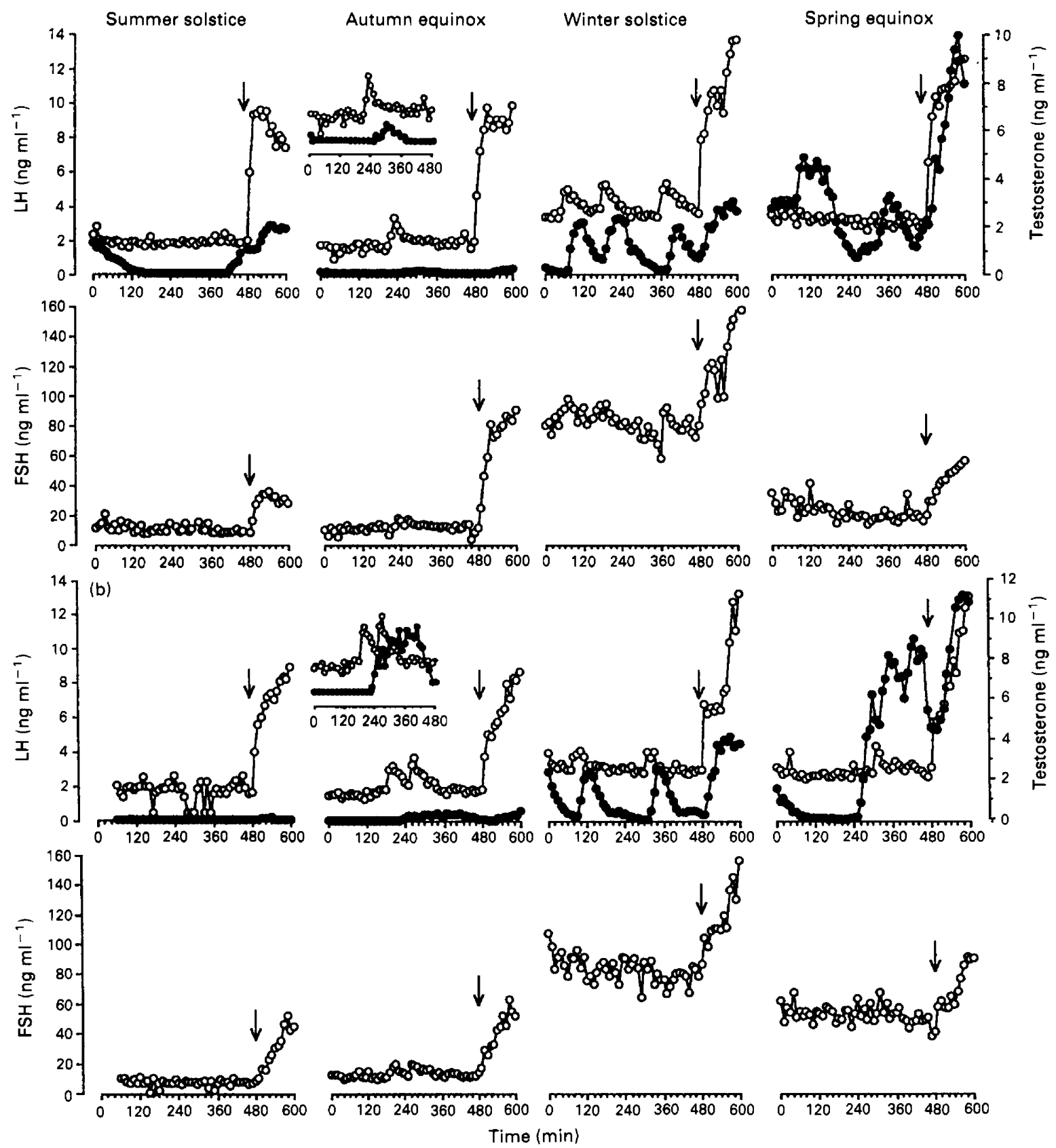

Fig. 1. Ten-hour serial blood sampling profiles for two representative stags ( $a$ and b) sampled within 2 weeks of the summer solstice, autumn equinox, winter solstice and spring equinox. (O) LH; (O) testosterone. $\mathrm{GnRH}\left(1 \mu \mathrm{g} \mathrm{kg}{ }^{-1}\right)$ was administered i.v. after the $480 \mathrm{~min}$ sample (arrow). Hormone concentration axes are expanded for the autumn sampling interval to reveal small, but distinct fluctuations in plasma testosterone relative to $\mathrm{LH}$ pulses. For inset panels: $\mathrm{LH}\left(0-4 \mathrm{ng} \mathrm{ml}^{-1}\right)$ and testosterone $\left(0-0.5 \mathrm{ng} \mathrm{ml} \mathrm{I}^{-1}\right)$ between 0 and $480 \mathrm{~min}$.

basal was higher $(P<0.05)$ during the spring than in autumn, there were no differences $(P>0.05)$ between spring and winter. Furthermore, no seasonal variation in mean testosterone pulse heights, expressed as a percentage increase above basal concentrations, was observed $(P>0.05)$.

Increases in $\mathrm{LH}$ and FSH after GnRH treatment were significant $(P<0.05)$ for all seasons (Fig. 2a, b) while testosterone concentrations were increased after $\mathrm{GnRH}$ treatment $(P<0.05)$ during all seasons except summer (Fig. 2c). The rise in LH after GnRH treatment was rapid, increasing $\geq 33 \%$ within $10 \mathrm{~min}$ (21 of $24,87.5 \%$ ) regardless of season $(P<0.05$ ). Basal $\mathrm{LH}$ was highest during the winter and spring, whereas the net $\mathrm{LH}$ increase (Table 2) after GnRH was similar $(P>0.05)$ for all seasons. In contrast, the proportional increase in $\mathrm{LH}$ was greatest $(P<0.05)$ during the summer and autumn when basal concentrations were lowest. The time required for FSH to increase 
Table 1. Comparison of pulse detection data (mean \pm SEM) for LH, FSH and testosterone during an $8 \mathrm{~h}$ period (before GnRH treatment) within 2 weeks of the summer solstice, autumn equinox, winter solstice and spring equinox for 6 Eld's deer stags

\begin{tabular}{|c|c|c|c|c|}
\hline Hormone & Summer & Autumn & Winter & Spring \\
\hline \multicolumn{5}{|l|}{$\mathbf{L H}$} \\
\hline Number of pulses in $8 \mathrm{~h}$ & $4.0 \pm 0.4^{e}$ & $2.5 \pm 0.2^{f}$ & $2.0 \pm 0.9^{f}$ & $1.8 \pm 0.3^{f}$ \\
\hline Mean pulse height as $\%$ increase $^{\mathrm{a}}$ & $122 \pm 6$ & $118 \pm 3$ & $119 \pm 3$ & $117 \pm 2$ \\
\hline Largest pulse height above basal ( $\left.\mathrm{ng} \mathrm{ml}^{-1}\right)^{\mathrm{b}}$ & $0.8 \pm 0.2$ & $1.1 \pm 0.2$ & $1.4 \pm 0.1$ & $1.1 \pm 0.1$ \\
\hline \multicolumn{5}{|l|}{ FSH } \\
\hline Number of pulses in $8 \mathrm{~h}$ & $2.8 \pm 1.0^{e}$ & $3.3 \pm 0.5^{\mathrm{e}}$ & $0.5 \pm 0.3^{f}$ & $1.7 \pm 0.9^{\mathrm{ef}}$ \\
\hline Mean pulse height as $\%$ increase $^{c}$ & $122 \pm 4$ & $120 \pm 2$ & $111 \pm 1$ & $119 \pm 4$ \\
\hline Largest pulse height above basal (ng ml $\left.{ }^{-1}\right)^{\mathrm{c}}$ & $6.4 \pm 1.0$ & $7.1 \pm 1.2$ & $16.0 \pm 1.3$ & $8.4 \pm 2.3$ \\
\hline \multicolumn{5}{|l|}{ Testosterone } \\
\hline Number of pulses in $8 \mathrm{~h}$ & $0.7 \pm 0.7^{\mathrm{e}}$ & $0.8 \pm 0.3^{\mathrm{ef}}$ & $2.0 \pm 0.0^{f g}$ & $2.5 \pm 0.4^{8}$ \\
\hline Mean pulse height as $\%$ increase $^{d}$ & $170^{-2 n}$ & $269 \pm 136$ & $298 \pm 49$ & $155 \pm 13$ \\
\hline Largest pulse height above basal ( $\left.\mathrm{ng} \mathrm{ml}^{-1}\right)^{d}$ & 0.3 & $0.3 \pm 0.1^{\mathrm{e}}$ & $2.2 \pm 0.2^{\mathrm{ef}}$ & $4.0 \pm 1.4^{\mathrm{f}}$ \\
\hline
\end{tabular}

${ }^{2} T$ The mean pulse height as a $\%$ increase represents the $\%$ increase of the mean peak amplitude above preceding nadir value.

${ }^{b}$ The largest pulse height above the basal value represents the incremental increase of the largest value expressed as the algebraic difference between the largest value and the preceding nadir.

'Winter data were excluded from seasonal comparisons because FSH pulses were detected only in 2 of 6 males.

dSummer data were excluded from seasonal comparisons because testosterone pulses were detected only in 1 of 6 males.

Within row means with different superscripts are significantly different $(P<0.05)$

$\geq 33 \%$ after $\mathrm{GnRH}$ was greatest $(P<0.05)$ during the winter $(78.3 \pm 18.5 \mathrm{~min})$ than in the summer, autumn and spring $(13.3 \pm 2.1 ; 16.7 \pm 4.9 ; 28.3 \pm 11.4$ min, respectively). Basal FSH concentrations were greatest $(P<0.05)$ during the winter than in all other seasons, whereas the net FSH increase after GnRH treatment ranged from only 20 to $40 \mathrm{ng} \mathrm{ml}^{-1}$ during all seasons. The proportional FSH increase during autumn was greater $(P<0.05)$ than that during winter and spring, but was not greater than the increase in summer. During the summer and autumn, testosterone concentrations after $\mathrm{GnRH}$ treatment did not increase $\geq 33 \%$ until $50.0 \pm 12.6 \mathrm{~min}$ and $70.0 \pm$ $12.6 \mathrm{~min}$, respectively. In contrast, testosterone concentrations after $\mathrm{GnRH}$ treatment increased faster $(P<0.05)$ during the winter $(25.0 \pm 5.6 \mathrm{~min})$ and spring $(33.3 \pm 5.6 \mathrm{~min})$. Testosterone concentrations before $\mathrm{GnRH}$ treatment and net increase in testosterone after $\mathrm{GnRH}$, were highest $(P<0.05)$ during the spring. Although there were no seasonal differences $(P>0.05)$ in the proportional increase in testosterone after $\mathrm{GnRH}$ treatment the net increase after $\mathrm{GnRH}$ was lower $(P<0.05)$ during the summer and autumn than during the winter and spring. Age, weight and antler size varied substantially among males, but there were no between-male differences $(P>0.05)$ in testosterone concentrations before or after GnRH treatment, or in the net or proportional increases in testosterone after $\mathrm{GnRH}$ treatment (Table 2). During the winter and spring, Eld's deer stags exhibited 1-3 distinct testosterone surges (Fig. 2c) during the 8-h basal sampling interval (09:00-17:00 h) before $\mathrm{GnRH}$ treatment. In 10 of 12 sampling periods, stags exhibited at least one surge in both the morning and afternoon.

\section{Discussion}

Although the testicular cycle in the Eld's deer is phase-shifted approximately 6 months compared with most temperate cervid species (Monfort et al., 1993), the interactive dynamics regulating the pituitary-gonadal axis were similar to those of red deer (Lincoln and Kay, 1979; Suttie et al., 1984) and fallow deer (Asher et al., 1989; Asher and Peterson, 1991). Eld's deer stags exhibited marked seasonal variations in basal concentrations of LH, FSH and testosterone. Although most LH pulses were not secreted coincidentally with FSH pulses, the trends of secretion of these two hormones were generally correlated. The lack of coincidental LH/FSH pulses may have been related to the higher FSH radioimmunoassay coefficients of variation used to perform the cluster analysis which made FSH pulse detection inherently more stringent. Other factors that probably dampened FSH pulsatility and hindered pulse detection were related to the greater seasonal increase in basal FSH secretion (summer to winter: FSH, 11-fold; LH, 2-fold) and the presumably longer half-life of FSH relative to $\mathrm{LH}$.

As with Eld's deer, red deer stags exhibited high amplitude, low frequency (4-6 h duration) testosterone surges (amplitude $>10.0 \mathrm{ng} \mathrm{ml}^{-1}$ ) during both the transition into the breeding season and during the rut that were always clearly associated with conspicuous LH pulses (Lincoln and Kay, 1979; Suttie et al., 1984). Fallow deer bucks (Asher et al., 1989; Asher and Peterson, 1991) also produced testosterone surges of $4-6 \mathrm{~h}$ duration (amplitude $10-25 \mathrm{ng} \mathrm{m}^{-1}$ ), but these often occurred in the absence of detectable LH pulses. Asher et al. (1989) suggested that these prolonged testosterone secretory episodes reflected 'maximal' testosterone secretion in response to chronically increased, nonpulsatile $\mathrm{LH}$ secretion. This theory suggested that $4-6 \mathrm{~h}$ was required to replenish testicular testosterone stores before the next secretory episode occurred. However, in Eld's deer stags, pharmacological doses of $\mathrm{GnRH}$ administered during or immediately after spontaneous testosterone surges induced further increases in testosterone, indicating that testicular reserves were not depleted. It appears more likely that testicular 

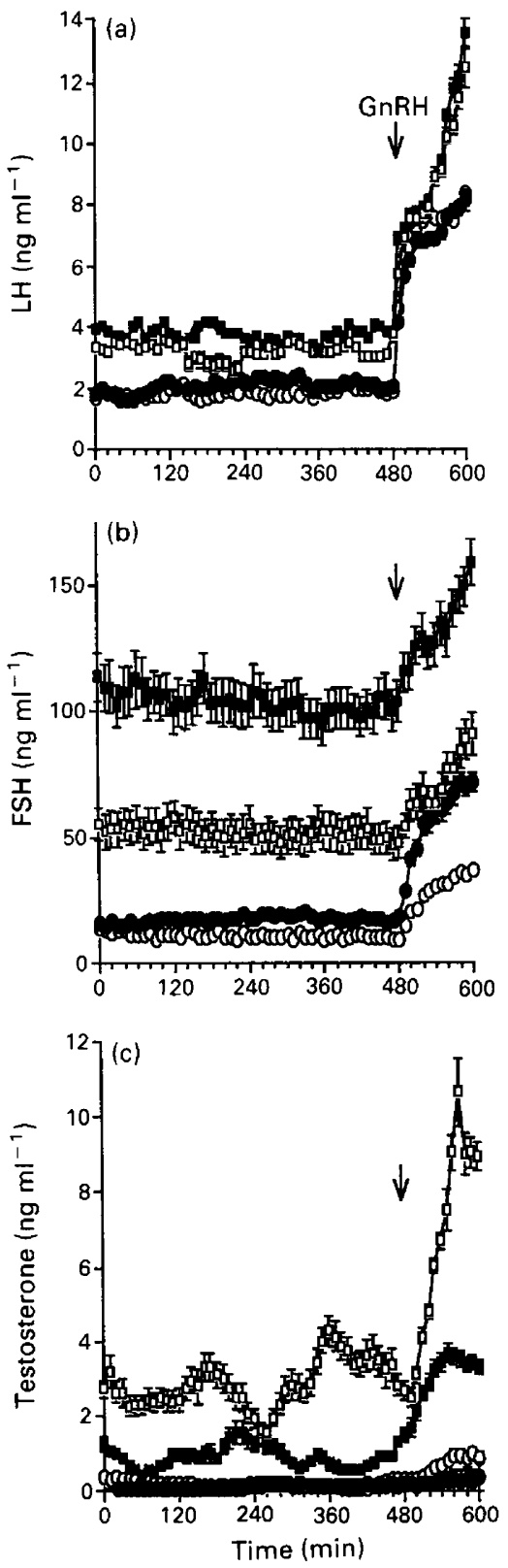

Fig. 2. Mean ( \pm SEM, $n=6$ males per season) (a) LH, (b) FSH and (c) testosterone profiles plotted by season (summer, 0 ; autumn, $O$; winter, $\mathbf{\square}$; spring, $\square$ ). Arrow denotes time of $\mathrm{GnRH}$ administration.

sensitivity to $\mathrm{LH}$ increased during the rut compared with the transition period before the rut, perhaps because of increased Leydig cell LH receptor concentrations. Thus, very modest LH pulses (difficult to detect using radioimmunoassay) may have been sufficient to induce substantial, sustained increases in testosterone. This assertion was supported by our Eld's deer data because (i) basal LH concentrations actually declined during the spring (rut) as testosterone concentrations were increasing, and (ii) a constant exogenous $\mathrm{GnRH}$ challenge across seasons resulted in a greater testosterone response during spring compared with winter.

Prolonged testosterone surges in the morning and afternoon have been reported to be synchronous among fallow bucks
(Asher and Peterson, 1991). Asher and Peterson (1991) suggested that this synchrony among males reflected entrainment of testicular secretory activity to a diurnal rhythm. The small standard errors associated with the mean testosterone surges in the study reported here during the winter and spring also suggests synchrony amongst Eld's deer stags. However, our sampling interval was insufficient to examine the possible existence of a definitive diurnal rhythm in testosterone secretion. Activity or social cues cannot be excluded as causes for this apparent synchrony (Asher and Peterson, 1991).

Both basal testosterone concentrations and pulse frequency were reduced during the hypogonadal period in the study reported here. Nonetheless, small broad-based, spontaneous testosterone pulses were first detected during the autumn that were closely associated with conspicuous $\mathrm{LH}$ pulses. The percentage increase in testosterone over basal concentrations at these times was substantial, suggesting that the secretory response dynamics of the testis to $\mathrm{LH}$ secretion was becoming re-activated. Thus, it appears that soon after the hypothalamic-pituitary axis redevelops the capacity to secrete high $\mathrm{LH}$ concentrations during the autumn, steroidogenic pathways also become partially activated, although peak testosterone concentrations are not observed until winter (Monfort et al., 1993). This continuum of long-duration episodic testosterone pulses appears to vary seasonally in frequency and amplitude, and larger increases in testosterone apparently reflect increased testicular responsiveness to $\mathrm{LH}$ as well as increased testicular steroidogenic capacity.

The pituitary-gonadal axis in male deer is well known to be responsive to exogenous GnRH (red deer, Lincoln and Kay, 1979; Suttie et al., 1984, 1989; Fennessy et al., 1988; white-tailed deer, Plotka et al., 1984; Bubenik et al., 1987; rusa deer, van Mourik et al., 1986). Lincoin and Kay (1979) first observed that testicular sensitivity to GnRH-induced LH (as measured by testosterone production) in red deer stags fluctuated with season and that maximum responsiveness occurred $1-2$ months before the rut. Suttie et al. (1984) demonstrated that red deer stags could respond to exogenous $\mathrm{GnRH}$ during all of the year, and that responsiveness was greatest when endogenous $\mathrm{LH}$ secretion was at nadir. Similarly, Fennessy et al. (1988) reported maximal pituitary and testicular responsiveness to $\mathrm{GnRH}$ in red deer stags when males were developing antler, but before rut, suggesting that there is a greater releasable pool of $\mathrm{LH}$ at this time. Responsiveness was diminished during rut, and this has been attributed to a suppressing impact of high, endogenous testosterone (Fennessy et al., 1988). A negative feedback role for testosterone has been supported by the finding that castrated males exhibit higher basal LH with increased pulse frequency and amplitude of LH secretion (red deer, Lincoln and Kay, 1979; fallow deer, Asher et al., 1989). In white-tailed bucks (Bubenik et al., 1987), maximal GnRH-induced pituitary LH secretion was greatest during the spring, whereas maximal testosterone secretion after $\mathrm{GnRH}$ occurred during the autumn rut. Similarly, rusa deer exhibited maximal GnRH-induced LH and testosterone secretion during the autumn and winter (rut), respectively (van Mourik et al., 1986). In the present study, basal LH and the proportional increase in $\mathrm{LH}$ after $\mathrm{GnRH}$ treatment was greatest during the summer and autumn (pre-rut), when basal concentrations were lowest. However, net GnRH-stimulated LH secretion was similar for all seasons. Thus, although basal LH secretion increased, the releasable pool of LH apparently 
Table 2. Mean ( \pm SEM) hormone concentrations before ( $n=3$ samples) and after ( $n=12$ samples) GnRH and the net and proportional increases in hormones from samples collected during an $8 \mathrm{~h}$ period within 2 weeks of the summer solstice, autumn equinox, winter solstice and spring equinox for six Eld's deer stags

\begin{tabular}{|c|c|c|c|c|}
\hline Hormone & Summer & Autumn & Winter & Spring \\
\hline \multicolumn{5}{|l|}{$\mathrm{LH}\left(\mathrm{ng} \mathrm{m} \mathrm{m}^{-1}\right)$} \\
\hline Pre-GnRH & $1.9 \pm 0.1^{\mathrm{c}}$ & $2.0 \pm 0.1^{c}$ & $3.9 \pm 0.3^{\mathrm{d}}$ & $3.3 \pm 0.4^{\mathrm{d}}$ \\
\hline Post-GnRH & $7.2 \pm 0.3^{c}$ & $6.8 \pm 0.4^{c}$ & $9.4 \pm 0.6^{\mathrm{d}}$ & $8.9 \pm 0.6^{\mathrm{d}}$ \\
\hline Net increase $\left(\mathrm{ng} \mathrm{ml}^{-1}\right)^{\mathrm{a}}$ & $5.4 \pm 0.3$ & $4.9 \pm 0.4$ & $5.5 \pm 0.6$ & $5.6 \pm 0.6$ \\
\hline Proportional increase $(\%)^{b}$ & $293 \pm 22^{c}$ & $251 \pm 32^{c}$ & $146 \pm 21^{\mathrm{d}}$ & $180 \pm 29^{d}$ \\
\hline \multicolumn{5}{|l|}{$\mathrm{FSH}\left(\mathrm{ng} \mathrm{ml} \mathrm{ml}^{-1}\right)$} \\
\hline Pre-GnRH & $9.4 \pm 0.6^{c}$ & $16.9 \pm 3.3^{\mathrm{cd}}$ & $103.4 \pm 20.9^{e}$ & $48.2 \pm 15.5^{\mathrm{d}}$ \\
\hline Post-GnRH & $28.9 \pm 1.3^{c}$ & $57.6 \pm 8.7^{\mathrm{cd}}$ & $133.4 \pm 19.0^{e}$ & $72.5 \pm 16.4^{\mathrm{d}}$ \\
\hline Net increase $\left(\mathrm{ng} \mathrm{ml}^{-1}\right)$ & $19.5 \pm 1.2^{c}$ & $40.8 \pm 8.8^{\mathrm{d}}$ & $29.9 \pm 5.7^{\mathrm{cd}}$ & $24.1 \pm 2.9^{c}$ \\
\hline Proportional increase (\%) & $214 \pm 23^{\mathrm{cd}}$ & $313 \pm 109^{c}$ & $37 \pm 11^{\mathrm{i}}$ & $72 \pm 18^{\mathrm{de}}$ \\
\hline \multicolumn{5}{|l|}{ Testosterone (ng ml ${ }^{-1}$ ) } \\
\hline Pre-GnRH & $0.31 \pm 0.16^{\mathrm{c}}$ & $0.16 \pm 0.05^{c}$ & $1.23 \pm 0.29^{c}$ & $2.90 \pm 0.74^{\mathrm{d}}$ \\
\hline Post-GnRH & $0.70 \pm 0.26^{\mathrm{c}}$ & $0.24 \pm 0.07^{c}$ & $3.07 \pm 0.49^{\mathrm{d}}$ & $6.80 \pm 0.77^{e}$ \\
\hline Net increase $\left(\mathrm{ng} \mathrm{ml}^{-1}\right)$ & $0.39 \pm 0.16^{\mathrm{c}}$ & $0.08 \pm 0.03^{\mathrm{c}}$ & $1.83 \pm 0.47^{\mathrm{d}}$ & $3.86 \pm 0.71^{\mathrm{e}}$ \\
\hline Proportional increase (\%) & $330 \pm 230$ & $51 \pm 14$ & $213 \pm 83$ & $184 \pm 48$ \\
\hline
\end{tabular}

\footnotetext{
aNet increase represents the mean hormone concentration after-GnRH minus the mean hormone concentration before GnRH.

'Proportional increase represents the mean hormone concentration after GnRH minus the mean hormone concentration before GnRH divided by the mean hormone concentration before $\mathrm{GnRH}$, expressed as a percentage.

Within row means with different superscripts are significantly different $(P<0.05)$.
}

remained relatively constant during all seasons, despite marked changes in basal testosterone secretion. The pituitary LH response was rapid (within $10 \mathrm{~min}$ ) during all seasons. Furthermore, unlike the situation in red deer (Lincoln and Kay, 1979; Fennessy et al, 1988), white-tailed deer (Plotka et al., 1984; Bubenik et al., 1987) and rusa deer (van Mourik et al., 1986), no differences were observed in either the proportional or net increase in GnRH-induced LH secretion during the pre-rut and rutting season.

Seasonal variation in pituitary responsiveness to $\mathrm{GnRH}$ in red deer has been reported using a wide range of GnRH doses $(0.5 \mu \mathrm{g}$, Lincoln and Kay, 1979; about $3 \mu \mathrm{g}$, Suttie et al., 1984; $95 \mu \mathrm{g}$, Fennessy et al., 1988). Pituitary challenge studies in rusa stags (van Mourik et al., 1986) revealed that LH responsiveness after GnRH-treatment was diminished during spring rut compared with the autumn (nonbreeding season); however, the relatively low dose (about $0.5 \mu \mathrm{g}$ ) of $\mathrm{GnRH}$ using in that study may partially explain the attenuated pituitary responsiveness during the rut. In white-tailed bucks (Plotka et al., 1984; Bubenik et al., 1987), pituitary responsiveness was also maximal during the pre-rut period and minimal during rut in response to administration of a pharmacological dose of GnRH (100-200 $\mu \mathrm{g})$. Consequently, disparities in pituitary responsiveness among species cannot be explained solely by differences in GnRH doses.

Despite apparent species differences in pituitary sensitivity, Eld's deer exhibited maximal testicular responsiveness to GnRH-induced LH during rut which was similar to that observed in red deer stags (Suttie et al., 1984) and white-tailed bucks (Plotka ef al., 1984). Although no seasonal trend in the proportional increase in testosterone was observed after $\mathrm{GnRH}$ treatment among Eld's deer stags, the net increase in testosterone rose in parallel with the increase in basal testosterone secretion. Thus, during the pre-rut and rutting seasons, both basal testosterone concentrations and testicular testosterone reserves were increasing. In addition, the increase in testosterone secretion after $\mathrm{GnRH}$ treatment generally occurred more rapidly as basal concentrations increased. Because both basal $\mathrm{LH}$ and the net releasable pool of $\mathrm{LH}$ remained relatively constant, increased speed and magnitude of testicular responsiveness to LH secretion induced by GnRH most likely represented increased testicular sensitivity to LH.

In white-tailed bucks, Bubenik et al. (1987) suggested that 'high quality' prime antler-bearers exhibited greater testicular responsiveness to exogenous $\mathrm{GnRH}$ challenges $(100 \mu \mathrm{g})$ than did 'low quality' weak antler-producers. These authors suggested that increased testicular responsiveness could be used as a screening test to pre-select superior antler-producing potential in juvenile bucks. In the present study, despite substantial differences in age, weight and antler size among males, there were no between-male differences in either testosterone secretion before and after $\mathrm{GnRH}$ treatment. Our data indicated that $\mathrm{GnRH}$-induced testosterone secretion may not be useful for pre-selecting superior antler-producers in all cervid species.

To our knowledge, this is only the second report describing pituitary FSH responsiveness to a GnRH challenge in any cervid. GnRH stimulated the release of FSH from the pituitary gland during all seasons. The proportional increase in FSH induced by $\mathrm{GnRH}$ was lowest during the winter and spring when basal FSH concentrations were highest. The net increase in FSH tended to be somewhat higher during the autumn and winter (before the rut), although during all seasons the average 
range in net increases only varied from 20 to $40 \mathrm{ng} \mathrm{ml}^{-1}$. In white-tailed bucks (Bubenik et al., 1987), FSH increased slightly after GnRH treatment during the autumn rut; however, FSH increased markedly after $\mathrm{GnRH}$ treatment during the spring. In contrast to white-tailed bucks (Bubenik et al., 1987), the capacity of the pituitary to secrete FSH in Eld's deer reached its peak during the winter. Although the FSH response to $\mathrm{GnRH}$ treatment was usually rapid (about $10 \mathrm{~min}$ ) during winter, the time required to achieve a $33 \%$ rise above already high basal concentrations was greatest at this time. Thus, like LH, the amount of FSH available to be released in response to a pharmacological $\mathrm{GnRH}$ dose remained relatively constant during all seasons. It therefore appeared that pituitary gonadotrophs in Eld's deer seasonally adjusted their secretory 'set point', but the reserve capacity to respond above basal concentrations to an exogenous $\mathrm{GnRH}$ challenge was constrained by a relatively constant releasable pool regardless of season.

Finally, this study demonstrated that intensive endocrine investigations are feasible even in fully conscious, highly excitable endangered species like the Eld's deer. This is particularly important because our knowledge about seasonal reproduction in tropical-zone species is generally lacking. Such information has been largely derived from studies in domestic sheep, temperate deer species and nonmuroid rodents. Thus, zoomaintained species serve as a valuable resource that provides researchers with unique opportunities to explore reproductive processes in nontraditional animal models.

This research was funded by an NIH Clinical Investigator Award to S. L. Monfort (HD 00903), grants from the Scholarly Studies Program of the Smithsonian Institution, the Friends of the National Zoo and the Women's Committee of the Smithsonian Associates. We especially thank M. Smak and the many volunteers of the Rivinus Barn for assisting with sample collection and P. Chakraborty and the Uniformed Services University for the Health Sciences, Bethesda, MD, USA for technical support.

\section{References}

Asher GW and Peterson AJ (1991) Pattern of LH and testosterone secretion in adult male fallow deer (Dama dama) during the transition into the breeding season Journal of Reproduction and Fertility 91 649-654

Asher GW, Peterson AJ and Bass JJ (1989) Seasonal pattern of LH and testosterone secretion in adult fallow deer, Dama dama Journal of Reproduction and Fertility $85657-665$
Brown JL, Stuart LD and Chakraborty PK (1987) Endocrine profiles, testicular gonadotropin receptors and sperm production in hemi-castrated ram lambs Journal of Animal Science 65 1563-1570

Brown JL, Wildt DE, Raath JR, de Vos V, Howard JG, Janssen DL, Citino SB and Bush M (1991) Impact of season on seminal characteristics and endocrine status of adult free-ranging African buffalo (Syncerus caffer) Journal of Reproduction and Fertility $92 \quad 47-57$

Bubenik GA, Morris JM, Schams D and Claus A (1982) Photoperiodicity and circannual levels of LH, FSH, and testosterone in normal and castrated male, white-tailed deer Canadian Journal of Physiology and Pharmacology 60 788-793

Bubenik GA, Schams D and Sempère A (1987) Assessment of reproductive and antler potential of the male white-tailed deer (Odocoileus virginianus) by $\mathrm{GnRH}$ stimulation test Comparative Biochemistry and Physiology 86A 767-771

Fennessy PF, Suttie JM, Crosbie SF, Corson ID, Elgar HJ and Lapwood KR (1988) Plasma LH and testosterone responses to gonadotrophin-releasing hormone in adult red deer (Cervus elaphus) stags during the annual antler cycle Joumal of Endocrinology 117 35-41.

Lincoln GA and Kay RNB (1979) Effects of season on the secretion of LH and testosterone in intact and castrated red deer stags (Cervus elaphus) Journal of Reproduction and Fertility 55 75-80

Loudon ASI and Curlewis JD (1988) Cycles of antler and testicular growth in an aseasonal tropical deer (Axis axis) Joumal of Reproduction and Fertility 83 729-738

Mirarchi RE, Howland BE, Scanlon PF, Kirkpatrick RL and Sanford LM (1978) Seasonal variation in plasma $\mathrm{LH}, \mathrm{FSH}$, prolactin, and testosterone concentrations in adult male white-tailed deer Canadian Journal of Zoology 56 $121-127$

Monfort SL, Wemmer C, Kepler TH, Bush M, Brown JL and Wildt DE (1990) Monitoring ovarian function and pregnancy in Eld's deer (Cervus eldi thamin) by evaluating urinary steroid metabolite excretion Journal of Reproduction and Fertility 88 271-281

Monfort SL, Brown JL, Bush M, Wood TC, Wemmer C, Vargas A, Williamson LR, Montali RJ and Wildt DE (1993) Circannual interrelationships among reproductive hormones, gross morphometry, behaviour, ejaculate characteristics and testicular histology in Eld's deer stags (Cerous eldi thamin) Journal of Reproduction and Fertility 98 471-480

Plotka ED, Seal US, Letellier MA, Verme LJ and Ozoga J] (1984) Early effects of pinealectomy on $\mathrm{LH}$ and testosterone secretion in white-tailed deer Journal of Endocrinology 103 1-7

Sempère AJ and Lacroix A (1982) Temporal and seasonal relationships between $\mathrm{LH}$, testosterone and antlers in fawn and adult male roe deer (Capreolus capreolus L.): a longitudinal study from birth to four years of age Acta Endocrinologica 99 295-301

Suttie JM, Lincoln GA and Kay RNB (1984) Endocrine control of antler growth in red deer stags Journal of Reproduction and Fertility 71 7-15

Suttie JM, Fennessy PF, Corson ID, Laas FJ, Elgar HJ and Lapwood KR (1989) LH and testosterone responses to GnRH in red deer (Cervus elaphus) stags kept in a manipulated photoperiod Journal of Reproduction and Fertility 85 213-219

van Mourik SA, Stelmasiak T and Outch KH (1986) Seasonal variation in plasma testosterone, luteinizing hormone concentrations and LH-RH responsiveness in mature male rusa deer (Cerous rusa timorensis) Comparative Biochemistry and Physiology 83A 347-351

Veldhuis JD and Johnson ML (1986) Cluster analysis: a simple, versatile, and robust algorithm for endocrine pulse detection American Joumal of Physiology 250 E486-493 